\title{
Topical Collection: Determining groundwater sustainability from long-term piezometry in Sub-Saharan Africa
}

\author{
Richard G. Taylor ${ }^{1}$ (D) $\cdot$ Guillaume Favreau $^{2}$ - Bridget R. Scanlon ${ }^{3} \cdot$ Karen G. Villholth $^{4}$
}

Received: 19 December 2018 / Accepted: 30 January 2019 / Published online: 22 February 2019

(C) The Author(s) 2019

\begin{abstract}
In Sub-Saharan Africa, groundwater use is a vital strategy to meet rapid increases in freshwater demand projected this century and to adapt to the region's substantial variabilities in rainfall and surface water resources, amplified by climate change. Four studies are considered, which constitute a topical collection of articles that provide new insight into the characteristics and processes by which groundwater is replenished, using recently compiled long-term groundwater-level records together with evidence from satellite data of the sustainability of exploited aquifer systems.
\end{abstract}

Keywords Sub-Saharan Africa $\cdot$ Piezometry $\cdot$ Groundwater recharge $\cdot$ Climate change $\cdot$ GRACE

\section{Introduction: sustainability of groundwater resources from long-term piezometry}

Groundwater is a vital source of freshwater in Africa, where rainfall and river discharge are among the most variable on the planet (McMahon et al. 2007; Niang et al. 2014). Compared to surface waters, groundwater provides a distributed, relatively low-cost and climate-resilient source of freshwater to address rapidly growing demand in Sub-Saharan Africa (SSA) associated with expanding access to safe water and enhancing food security through irrigation (Taylor et al. 2009; Braune and Xu 2010; Villholth 2013; Altchenko and Villholth 2015). These development agendas are enshrined in the UN Sustainable Development Goal (SDG) 2 to end hunger, achieve food security and promote sustainable agriculture,

This article is part of the topical collection "Determining groundwater sustainability from long-term piezometry in Sub-Saharan Africa"

Richard G. Taylor

richard.taylor@ucl.ac.uk

1 UCL Geography, Gower Street, London WC1E 6BT, UK

2 Institut de Recherche pour le Développement (IRD), 276 Avenue de Maradi, Niamey, Niger

3 Jackson School of Geosciences, Bureau of Economic Geology, University of Texas at Austin, Austin, TX, USA

4 IWMI Southern Africa Office, X813, Silverton, Pretoria 0127, South Africa and SDG 6 to ensure availability and sustainable management of water and sanitation for all, by 2030 .

Groundwater storage in Africa is estimated to be $\sim 100$ times greater than annual river discharge but varies substantially from the regional sedimentary basins of North Africa, with an equivalent water depth of $50 \mathrm{~m}$, to weathered crystalline rocks, which underlie much of equatorial Africa and have an equivalent depth of just $0.5 \mathrm{~m}$ (MacDonald et al. 2012). Sustainability in groundwater use is constrained by storage and, in the long term, by its renewability. Fundamental uncertainties persist, however, about the magnitude and nature of groundwater recharge as well as the impacts of climate extremes/change and land-cover change on groundwater storage.

Long-term (decadal) time series of observed groundwater levels (chronicles) constitute the most direct and robust indicator of local storage changes in aquifer systems - for example, chronicles in Niger provide evidence of "The Sahelian Paradox" showing an unexpected rise in groundwater levels during an extended drought in response to widespread conversion of perennial grasslands to shallow-rooted crops (Favreau et al. 2009). In Tanzania, near-continuous chronicles over a 55-year period reveal that groundwater recharge depends on episodic, heavy seasonal rainfall associated with the El Niño Southern Oscillation (ENSO) (Taylor et al. 2013). Questions remain, however, regarding the representativity of individual chronicles and the role of local factors in controlling piezometric responses. In this respect, the emergence of recent national-scale groundwater-level monitoring 
networks in Benin, Burkina Faso, Niger and Uganda, similar to that in South Africa, is a very promising development, as such records will lay the foundation for assessing groundwater sustainability in the future. Finally, substantial uncertainty relates to values of specific yield $\left(S_{\mathrm{y}}\right)$ applied to convert the amplitude of groundwater-level changes into recharge and discharge (Healy and Cook 2002). New evidence from magnetic resonance sounding experiments in Benin (Kotchoni et al. this issue) reveals the magnitude of variability in $S_{\mathrm{y}}$ that can occur under different geological conditions and its impact on groundwater recharge estimates.

\section{The Chronicles Consortium}

At the 41st Congress of the International Association of Hydrogeologists (IAH) in Marrakech (Morocco) in 2014, an international consortium of scientists, The Chronicles Consortium (IGRAC 2018), was established to review the availability of chronicles in Sub-Saharan Africa and examine whether these might collectively enable an evaluation of changes in groundwater storage across the broad range of climate and geological settings that characterise this region. While the existence of multi-decadal chronicles in several countries in SSA has long been known (e.g. Bazie et al. 1995; Beekman and Xu 2003; Favreau et al. 2009; Owor et al. 2009; Sibanda et al. 2009; Taylor et al. 2013; Murray et al. 2018), the innovative goal of the consortium is to collate and analyse these records systematically in order to maximise understanding of how climate extremes/change, land-use change, and groundwater withdrawals impact groundwater storage across the region. This collaborative endeavour of the African Groundwater Network (AGW-Net), IAH Commission on Groundwater and Climate Change (IAHCGCC), and UNESCO-IHP GRAPHIC (Groundwater Resources Assessment under the Pressures of Humanity and Climate Change) is supported, in part, by the UK government through the NERC-ESRC-DFID UPGro (Unlocking the Potential of Groundwater for the Poor) programme, IRD (Institut de Recherche pour le Développement) France, and the government of The Netherlands through the UNESCO centre, IGRAC (International Groundwater Resources Assessment Centre).

A series of meetings at subsequent annual congresses of the IAH in Rome (Italy) in 2015 and Montpellier (France) in 2016, as well as dedicated workshops in Uganda and Benin, focused on establishing the integrity and interpretability of collated chronicles. Considerable time was spent interrogating each chronicle and resolving errors that included data-entry issues, transcription errors from chart recorders, and datum problems (e.g. Maurice et al. this issue). Indeed, a substantial proportion of collated chronicles had to be discarded from further analysis. Closer monitoring of data collection and greater use of observational records are required to improve the quality of these datasets. A capacity-strengthening and knowledge co-production workshop was held at Sokoine University of Agriculture in Morogoro (Tanzania) in February 2017. The workshop involved 40 participants from 11 countries in Africa (Fig. 1) who analysed multi-decadal groundwater-level records collated from 9 countries including Benin, Burkina Faso, Ghana, Niger, Sénégal, South Africa, Tanzania, Uganda and Zimbabwe. Participants included PhD students and more experienced researchers as well as representatives from government ministries and the private sector.

\section{Climate, geology and groundwater recharge and storage}

This essay describes the four papers in the topical section in this issue. These papers provide a sample of the new research outputs emanating from The Chronicles Consortium. Evidence from chronicles in seasonally humid Benin (Kotchoni et al. this issue) and Uganda (Maurice et al. this issue) show annual cycles of replenishment from direct, diffuse recharge generated preferentially by heavy rainfalls. Kotchoni et al. (this issue) show further how chronicles from different geological environments in Benin can be modelled very effectively on a daily timestep with an improved watertable fluctuation model using a simple scalar of precipitation exceeding a threshold to compute recharge. Discharge characteristics of these chronicles, remote from intensive pumping, are represented well using both linear and exponential recessions. Of note in this study is that the common uncertainty over the magnitude of applied $S_{\mathrm{y}}$ to represent groundwaterlevel fluctuations is reduced by field experiments using magnetic resonance sounding.

In semi-arid southwestern Niger, Abdou Babaye et al. (this issue) employ chronicles to show that recharge to weathered crystalline rock aquifer systems occurs directly from rainfall but is restricted by a thick clayey aquitard developed from schist; greater recharge is shown to occur indirectly via riverbeds of ephemeral streams which provide preferential pathways through the saprolite. Evidence from the Makutapora Wellfield of semi-arid central Tanzania (Maurice et al. this issue) confirms that groundwater, abstracted at rates exceeding $30,000 \mathrm{~m}^{3} /$ day, is sustained by episodic recharge associated with ENSO. Further, residence-time indicators of CFCs, $\mathrm{SF}_{6}$ and ${ }^{3} \mathrm{H}$ show that abstracted groundwater is partially modern, derived from rainfall within the last 10-60 years.

Studies from Benin (Kotchoni et al. this issue) and Niger (Abdou Babaye et al. this issue) highlight the low storage of weathered crystalline rock aquifers and the importance of modern recharge in sustaining groundwater use. The low storage and low but highly variable hydraulic conductivity of weathered and fractured crystalline rock aquifers found over 


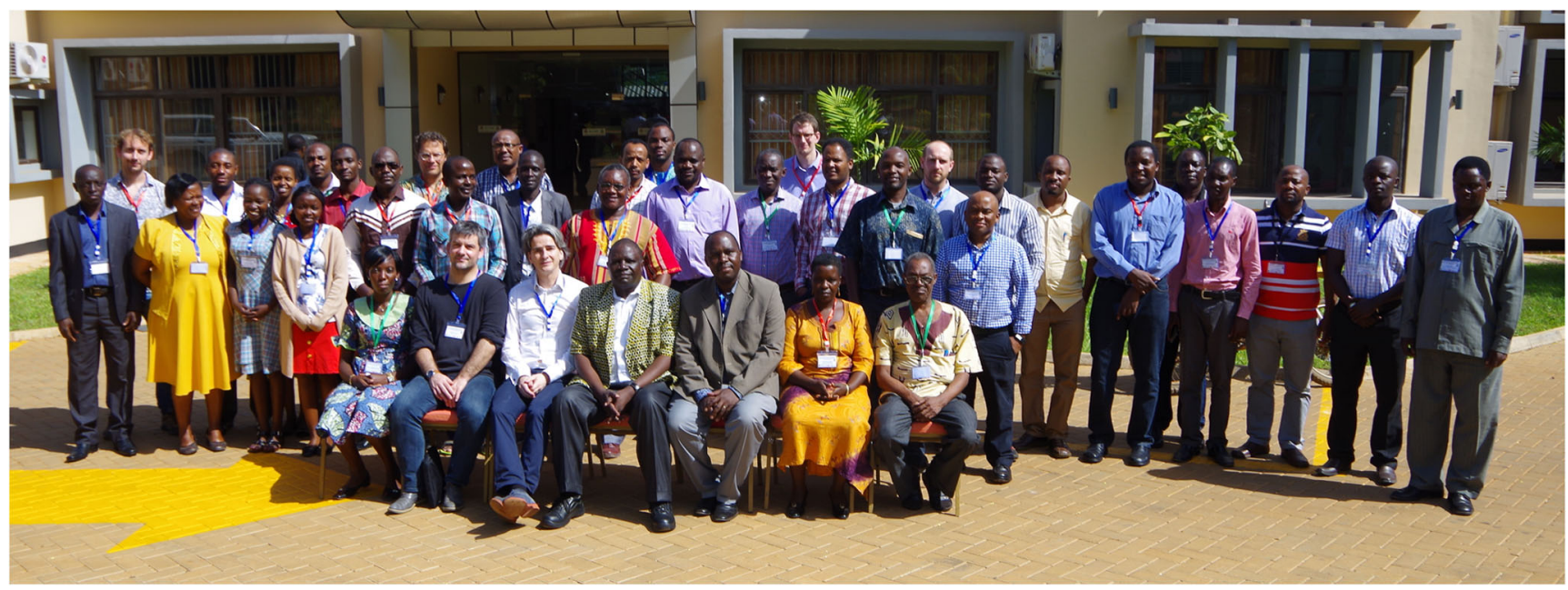

Fig. 1 Participants from 11 countries in Africa as well as the United Kingdom and France at The Chronicles Consortium workshop held at Sokoine University of Agriculture in Morogoro, Tanzania, from 10th to 12th February 2017

more than $40 \%$ of Sub-Saharan Africa (MacDonald et al. 2012) may, however, have a potential advantage. Such aquifer systems restrict opportunities for intensive (e.g. $>2 \mathrm{~L} \mathrm{~s}^{-1}$ ) and competitive abstraction and are thus potentially self-regulating. Low-intensity groundwater abstraction distributed across the landscape also complements existing land-tenure systems in many areas of Sub-Saharan Africa dominated by smallholder agriculturalists (Villholth 2013).

The assembled chronicles provide invaluable datasets to facilitate direct assessments of past impacts of climate variability-e.g. ENSO, Atlantic Multi-decadal Oscillation (AMO) - (Carvalho et al. this issue) and abstraction (e.g. Maurice et al. this issue) on groundwater storage. Such records, when continuously updated, can also provide key input to water resources management by tracking emerging risks to water security from groundwater storage decline or groundwater flooding (e.g. Murray et al. 2018). Regional-scale $\left(>50,000 \mathrm{~km}^{2}\right)$ networks of long-term piezometric records (e.g. Shamsudduha et al. 2012; Kolusu et al. 2018; Carvalho et al. this issue) can also be used to test the reliability of largescale, satellite observations from the Gravity Anomaly and Climate Experiment (GRACE). Indeed, the emergence of GRACE measurements of changes in total terrestrial water storage (Tapley et al. 2004) adds a potential tool, albeit at a much larger scale $\left(>200,000 \mathrm{~km}^{2}\right)$, to estimate changes in groundwater storage where in situ piezometric records do not exist (Famiglietti 2014). Analyses in Sub-Saharan Africa (e.g. Shamsudduha et al. 2017; Bonsor et al. 2018) highlight substantial uncertainty in GRACE-derived groundwater storage changes due primarily to uncertainty in the use of landsurface models to account for changes in other terrestrial stores (i.e. soil, surface water) and deduct these from the GRACE measurement of total terrestrial water storage. This uncertainty explains, in part, the focus of the one GRACE paper in this topical collection (Carvalho et al. this issue) on changes in total freshwater storage from GRACE satellite data and demonstrates the critical control of rainfall variability related to large-scale climate controls (e.g. ENSO) on total freshwater storage.

\section{Concluding thoughts}

Substantial increases in groundwater withdrawals are expected across Sub-Saharan Africa to help nations increase access to safe water and to amplify agricultural production in pursuit of UN SDG 2 and SDG 6. The potential of groundwater to contribute sustainably to this development agenda will likely be controlled, to a substantial extent, by local-scale economic and socialpolitical factors that enable or inhibit access to groundwater resources and its management. Long-term groundwater-level records or chronicles nevertheless will play an important role in developing an improved understanding of the hydrogeological and climatic conditions that control access and sustain well yields, informing where, when and how groundwater withdrawals can sustainably contribute to building resilience and alleviating poverty, as represented by the UN SDGs.

Open Access This article is distributed under the terms of the Creative Commons Attribution 4.0 International License (http:// creativecommons.org/licenses/by/4.0/), which permits unrestricted use, distribution, and reproduction in any medium, provided you give appropriate credit to the original author(s) and the source, provide a link to the Creative Commons license, and indicate if changes were made.

\section{References}

Altchenko Y, Villholth KG (2015) Mapping irrigation potential from renewable groundwater in Africa: a quantitative hydrological approach. Hydrol Earth Syst Sci 19:1055-1067 
Abdou Babaye MS, Orban P, Ousmane B, Favreau G, Brouyère S, Dassargues A (this issue) Characterization of recharge mechanisms in a Precambrian basement aquifer in semi-arid South-West Niger. Hydrogeol J. https://doi.org/10.1007/s10040-018-1799-x

Bazie P, Dieng B, Ackerer P (1995) Bilan des transferts verticaux d'eau en zone non-saturée sous climat soudano-sahélien: application à l'estimation de la recharge des nappes [Balance of vertical water transfers in the unsaturated zone under Sudano-Sahelian climate: application to the estimation of groundwater recharge]. Rev Sci Eau 8:237-260

Beekman HE, Xu Y (2003) Review of groundwater recharge estimation in arid and semi-arid Southern Africa. In: Xu Y, Beekman HE (eds) Groundwater recharge estimation in southern Africa. UNESCO IHP Series no. 64, UNESCO, Paris, pp 3-18

Bonsor HC, Shamsudduha M, Marchant BP, MacDonald AM, Taylor RG (2018) Seasonal and decadal groundwater changes in African sedimentary aquifers estimated using GRACE products and LSMs. Remote Sens 10:904

Braune E, Xu Y (2010) The role of ground water in Sub-Saharan Africa. Ground Water 48(2):229-238

Carvalho RT, Longuevergne L, Gurdak JJ, Leblanc M, Favreau G, Ansems N, Van der Gun J, Gaye CB, Aureli A (this issue) Assessment of the impacts of climate variability on total water storage across Africa: implications for groundwater resources management. Hydrogeol J. https://doi.org/10.1007/s10040-018-1864-5

Famiglietti JG (2014) The global groundwater crisis. Nat Clim Chang 4: 945-948

Favreau G, Cappelaere B, Massuel S, Leblanc M, Boucher M, Boulain N, Leduc C (2009) Land clearing, climate variability, and water resources increase in semiarid Southwest Niger: a review. Water Resour Res 45:WR006785

Healy RW, Cook PG (2002) Using groundwater levels to estimate recharge. Hydrogeol J 10:91-109

IGRAC (2018) The Chronicles Consortium. International Groundwater Resources Assessment Centre (IGRAC). https://www.un-igrac.org/ special-project/chronicles-consortium. Accessed December 2018

Kolusu SR, Shamsudduha M, Todd MC, Taylor RG, Seddon D, Kashaigili JJ, Ebrahim GY, Cuthbert MO, Sorensen JPR, Villholth KG, MacDonald AM, MacLeod DA (2018) The El Niño event of 2015-16: climate anomalies and their impact on groundwater resources in east and southern Africa. Hydrol Earth Syst Sci Discuss. https://doi.org/10.5194/hess-2018-516

Kotchoni DOV, Vouillamoz J-M, Lawson FMA, Adjomayi P, Boukari M, Taylor RG (this issue) Relationships between rainfall and groundwater recharge in seasonally humid Benin: a comparative analysis of long-term hydrographs in sedimentary and crystalline rock aquifers. Hydrogeol J. https://doi.org/10.1007/s10040-018-1806-2
MacDonald A, Bonsor HC, O Dochartaigh BE, Taylor RG (2012) Quantitative maps of groundwater resources in Africa. Environ Res Lett 7:024009

Maurice L, Taylor RG, Tindimugaya C, MacDonald AM, Johnson P, Kaponda A, Owor M, Sanga H, Bonsor HC, Darling WG, Gooddy D (this issue) Characteristics of high-intensity groundwater abstractions from weathered crystalline bedrock aquifers in East Africa. Hydrogeol J. https://doi.org/10.1007/s10040-018-1836-9

McMahon TA, Vogel RM, Pegram GGS, Peel MC, Etkins D (2007) Global streamflows, part 2: reservoir storage - yield performance. J Hydrol 347:260-270

Murray R, Louw D, van der Merwe B, Peters I (2018) Windhoek, Namibia: from conceptualising to operating and expanding a MAR scheme in a fractured quartzite aquifer for the city's water security. Sust Wat Resour Mgmt 4:217-223

Niang I, Ruppel OC, Abdrabo MA, Essel A, Lennard C, Padgham J, Urquhart P (2014) Africa. In: Climate Change 2014: Impacts, Adaptation, and Vulnerability, part B: Regional Aspects. Contribution of Working Group II to the Fifth Assessment Report of the Intergovernmental Panel on Climate Change Cambridge University Press, Cambridge, pp 1199-1265

Owor M, Taylor RG, Tindimugaya C, Mwesigwa D (2009) Rainfall intensity and groundwater recharge: evidence from the upper Nile Basin. Environ Res Lett 4:035009

Shamsudduha M, Taylor RG, Longuevergne L (2012) Monitoring groundwater storage changes in the Bengal Basin: validation of GRACE measurements. Water Resour Res 48:W02508

Shamsudduha M, Taylor RG, Jones D, Longuevergne L, Owor M, Tindimugaya $C$ (2017) Recent changes in terrestrial water storage in the upper Nile Basin: an evaluation of commonly used gridded GRACE products. Hydrol Earth Syst Sci 21:4533-4549

Sibanda T, Nonner JC, Uhlenbrook S (2009) Comparison of groundwater recharge estimation methods for the semi-arid Nyamandhlovu area, Zimbabwe. Hydrogeol J 17:1427-1441

Tapley BD, Bettadpur S, Ries JC, Thompson PF, Watkins MM (2004) GRACE measurements of mass variability in the earth system. Science 305:503-505

Taylor RG, Koussis A, Tindimugaya C (2009) Groundwater and climate in Africa: a review. Hydrol Sci J 54(4):655-664

Taylor RG, Todd M, Kongola L, Nahozya E, Maurice L, Sanga H, MacDonald A (2013) Evidence of the dependence of groundwater resources on extreme rainfall in East Africa. Nat Clim Chang 3:374 378

Villholth KG (2013) Groundwater irrigation for smallholders in SubSaharan Africa: a synthesis of current knowledge to guide sustainable outcomes. Water Int 38:369-391 